DOI 10.22363/2313-1683-2020-17-4-705-718

UDC 316.6

Research article

\title{
The Relationships \\ between Moral Foundations, Social Beliefs and Attitudes towards Economic Inequality among Russian Youth: A Case Study of Altai Krai
}

\author{
Oleg A. Sychev, Irina N. Protasova \\ Shukshin Altai State University for Humanities and Pedagogy \\ 53 Korolenko St, Biysk, 659333, Russian Federation
}

\begin{abstract}
This article presents the results of an empirical study on the relationships between moral foundations, social beliefs and attitudes towards economic inequality among young people. The topic of attitudes towards economic inequality has primarily been considered by sociologists and economists in the context of group differences, while its psychological factors and correlations have remained understudied. Different negative consequences of economic inequality can be mediated by such psychological mechanisms as subjective perception of existing inequality or personal attitudes towards it, which indicate the significance of this problem. In our study, we put forward a hypothesis that attitudes towards economic inequality among young people are related to moral foundations and social beliefs. To test this hypothesis, a study was conducted with a sample of 215 students ( $21 \%$ of the sample were male). The subjects completed The Scales of Dangerous World Beliefs and Jungle World Beliefs by J. Duckitt, The Moral Foundations Questionnaire by J. Graham and colleagues, and The Scale of Beliefs about Inequality by J. Kluegel and E. Smith. One of the objectives of this study was the development of a Russian version of the questionnaire by J. Kluegel and E. Smith, which full version is given in the appendix of the article. The correlations revealed that attitudes towards inequality are related to moral foundations (fairness, purity, and loyalty) and beliefs in a jungle world. Additionally, structural equation modeling has shown that approval of equality and inequality is most closely related to family welfare. Furthermore, this study found that the relationship between attitudes towards inequality and individualizing moral foundations is mediated by beliefs in a jungle world. Thus, sense of fairness and the value of caring for the weak and defenseless is opposed to beliefs in a jungle world and approval of inequality.
\end{abstract}

Key words: economic inequality, moral foundations theory, fairness, social beliefs, beliefs in a jungle world

\section{Introduction}

Economic inequality has attracted considerable attention of economists, sociologists and, more recently, psychologists due to the many negative consequences of excessive inequality (Norton, Ariely, 2011; Telin, 2019; Zhuravlev, Yurevich,

(C) Sychev O.A., Protasova I.N., 2020

(c) (i) This work is licensed under a Creative Commons Attribution 4.0 International License https://creativecommons.org/licenses/by/4.0/ 
2018). The danger of excessive inequality was recently analyzed in detail by A.L. Zhuravlev and A.V. Yurevich (2018), who not only listed its consequences in various spheres of public life but also raised the question of their socio-psychological mediation. Inequality is a concern not only for scientists: according to a study conducted by Ipsos Group S. A. in 28 countries (March 2018), poverty and social inequality are among the most worrisome threats in these countries and, very significantly, our compatriots mentioned this threat much more often than most others did (see Nestik, Zhuravlev, 2018. P. 27). One of the difficulties in the study of economic inequality is that it is not limited to economic indicators but also includes the subjective aspect of perception or assessment of inequality (Telin, 2019), so the growing interest in this problem on the part of psychologists seems to be quite natural.

Perceptions of and attitudes towards inequality have been studied primarily in economics and sociology, with a focus on the differences between various social groups. In particular, it has been found that wealthy people treat income inequality better than poor people do (Roex et al., 2019). Along with the level of welfare, attitudes towards inequality are influenced by myths or narratives that reflect ideas about the causes of wealth, inequality and social order. For example, a positive attitude towards inequality in society is supported by the narratives of "procedural justice" (the poor and the rich have equal rights and opportunities) and "middle class" (the growth of the middle class eliminates the contradiction between the poor and the rich) (Larsen, 2016). In the context of attitudes towards inequality, the meritocratic beliefs are also important, implying that wealth and status are deservedly acquired. It is known that such perceptions in society reinforce the polarisation of views on inequality between the rich and the poor (Roex et al., 2019). This is explained in terms of social identity theory by the fact that it is difficult for the poor to maintain a positive identity by accepting such beliefs; therefore, they are more likely to reject them and less likely to justify inequality.

In the subjective dimension of inequality, different aspects can be distinguished, whereas most of the research is centred on two sides of it, designated by the concepts of 'perceived inequality' and 'attitudes towards inequality'. Perceived inequality characterises an individual's perception of how unequally resources are distributed within society (Kim et al., 2018). To assess this aspect, questionnaires (García-Castro et al., 2019) or various less formalised procedures are used, including graphical scales, diagrams, and questions that reveal ideas about the distribution of resources in society (Norton, Ariely, 2011). Using these methods, it is possible to obtain data only on how great, according to respondents, the differences in the level of welfare in society are, but their attitudes towards these differences is not the subject of assessment. Another subjective aspect of inequality, in contrast, reflects not the perceived distribution of resources, but how people treat economic inequality, i.e. whether they support or reject it. Attitudes towards inequality are also measured using standardized questionnaires, the content of which is directly related to support or rejection of inequality (Kluegel, Smith, 1986; Wiwad et al., 2019) or questions that require respondents to express their preferences, choosing a more or less equal distribution of income in society (Norton, Ariely, 2011).

In various sciences, important information has been obtained describing the perception of inequality and attitudes towards it in various social groups; however, individual differences in attitudes towards inequality associated with psy- 
chological characteristics remain poorly understood. Among the probable psychological factors that determine attitudes towards inequality are social beliefs reflecting a person's ideas about what the essence of other people is, how they behave in relation to others and how to respond to their actions (Gulevich et al., 2014). Social beliefs mediate the relationship between personality traits and personal attitudes, influencing socio-political views in relation to a variety of social objects, phenomena and the choice of life goals.

In the context of the problem of economic inequality, the most interesting social belief is the belief in a competitive (jungle) world, which includes the belief that other people are rivals and, in order to win the competition, it is necessary to use all opportunities, not limiting oneself by moral norms, since others behave in a similar way. The belief in a jungle world is the basis of a social dominance orientation that includes approval of social inequality and intragroup hierarchy (Duckitt et al., 2002). In the available literature, we failed to find studies of the relationship between social beliefs and attitudes towards income inequality, but we can assume the existence of this relationship, given the similar content of the constructs 'attitude to inequality' and 'commitment to social dominance'. Less relevant to the problem of attitudes towards inequality is another social belief, namely, the belief in a dangerous world, which implies that society is chaotic, unpredictable and unsafe (Duckitt et al., 2002).

Inequality is often frowned upon because it contradicts some moral norms and ideas about a just society. In this regard, among the factors influencing attitudes towards inequality, we should take into account the peculiarities of a person's moral sphere, which can be characterised in terms of Moral Foundations Theory (MFT) (Haidt, Bjorklund, 2008; Graham et al., 2013). The founder of this theory, a prominent representative of positive psychology, J. Haidt, repeatedly drew attention to the fact that deep differences in the moral sphere are hidden behind political and economic discussions (Haidt et al., 2009; Randazzo, Haidt, 2015).

According to MFT, there are five main 'dimensions' of morality, reflecting the generalised criteria of moral assessment, namely Care, Fairness, Loyalty, Authority and Purity (or Sanctity). The first two dimensions are called 'individualizing' moral foundations, since they mainly concern the relationship between individuals, while the other three are 'binding', since they are more concerned with the relationship between individuals and society. This approach is quite fully both in Englishlanguage (Haidt, Bjorklund, 2008; Haidt et al., 2009; Graham et al., 2011; Graham et al., 2013) and Russian-language publications (Zaikin, 2017; Kozlova, Kozlov, 2016; Sychev et al., 2016), so there is no need for its detailed consideration. Note that in a recent MFT-based study conducted by A. Franks and K. Scherr data were obtained that attitudes towards inequality are indeed associated with the characteristics of the moral sphere (Franks, Scherr, 2019). The greatest contribution to attitudes towards inequality was shown by the moral foundations of Fairness and Purity. In addition, their work fully confirmed the conclusions of M. Norton and D. Ariely that most Americans significantly underestimate the real degree of inequality existing in their country but still believe that inequality must be reduced (Norton, Ariely, 2011).

Thus, based on a review of past research, it has been suggested that young people's attitudes towards economic inequality are related to moral foundations and social beliefs, with the latter acting as a mediator of the relationship between 
the moral sphere and attitudes towards inequality. Among the factors, the influence of which on attitudes towards inequality must be controlled, we took into account Gender, Age and Material Welfare. Since there is no reliable instrument for measuring attitudes towards inequality, one of our tasks was to develop a Russian version of The Scale of Beliefs about Inequality by J. Kluegel and E. Smith (Kluegel, Smith, 1986) with a preliminary analysis of its psychometric characteristics. This questionnaire was chosen due to its good theoretical validity and a long history of use in combination with acceptable psychometric characteristics.

\section{Methods}

Participants. The study involved 215 full-time and part-time students of Shukshin Altai State University for Humanities and Pedagogy at the age from 18 to 35 years, the average age $=25.37$, the standard deviation $=5.41$, the proportion of men in the sample $=21 \%$. The sample composition of young and middle-aged people was one of the reasons for using Age as a control variable in data analysis.

Research methods. To assess attitudes towards social inequality, we used an adapted version of The Scale of Beliefs about Inequality (Kluegel, Smith, 1986). When developing the questionnaire, the authors relied on the concept of inequality arising from three main socio-economic approaches: (1) structural functionalism (considering inequality as a natural consequence of different contributions made by different people to society), (2) A. Smith's classical political economy (interpreting inequality as a consequence of actions of capital owners) and (3) Marxist theory (considering inequality as a factor in class struggle, social conflict). This questionnaire includes 11 statements: seven of them measure the degree of acceptance of income inequality in society and the remaining four assess the preference for more equality. Previous studies have shown a two-factor structure of the questionnaire, corresponding to the equality and inequality scales with satisfactory reliability of each of the scales (0.65 and 0.88 , respectively) (Bullock et al., 2003). While developing the Russian-language version, two specialists (a psychologist and a linguist) independently prepared a translation of the text of the items, which was then discussed in terms of its compliance with the original, on the one hand, and the realities of Russian society, on the other hand. After the wording was clarified, the text was used for the survey (see the full Russian version in Appendix). Data on the factor structure and reliability of the scales for the proposed version of the questionnaire are given below in the "Results" section. In a quantitative assessment of the results, the average values of estimates were calculated for the statements included in the factors 'approval of equality' (Statements 1-4, all direct, see the text in Table 2) and 'approval of inequality' (Statements 5-11, all direct).

Social beliefs were measured using J. Duckit's scales designed to diagnose dangerous world belief and jungle world beliefs, as adapted by O.A. Gulevich, O.A. Anikeenok and I.A. Bezmenova (Gulevich et al., 2014). Each of the scales includes 12 statements, agreement with which must be assessed on a five-point scale. The reliability coefficient values (hereinafter, Cronbach's $\alpha$ are given) in this study were 0.69 for the scale of beliefs in a dangerous world and 0.77 for the scale of beliefs in a jungle world.

To diagnose the moral sphere, we used The Moral Foundations Questionnaire by J. Graham and others (Graham et al., 2011) adapted by O.A. Sychev, I.N. Pro- 
tasova and K.I. Belousov (Sychev et al., 2018). The questionnaire consists of 30 tasks (two parts of 15 items each), forming five scales, namely Care, Fairness, Loyalty, Authority and Purity. The processing of the results included the calculation of the mean scores for each respondent on the scales as well as the mean scores on the second-level scales: Individualizing moral foundations, including the scales of Care and Fairness, and Binding moral foundations, formed by the scales of Loyalty, Authority and Purity. Besides that, an additional indicator was used, i.e., the coefficient of progressivism, which characterises the balance between the individualizing and binding moral foundations and is calculated as the difference between them.

The reliability coefficients of the five first-level scales in this study ranged from 0.67 to 0.74 ; for the individualizing and binding moral foundations, they were 0.83 and 0.85 , respectively.

To assess material welfare, we used the Index of Current Family Welfare scale from the questionnaire of subjective economic welfare by V.A. Khashchenko (Khashchenko, 2011), which includes four items with a five-point scale of answers. This questionnaire is the only Russian-language tool for assessing subjective economic welfare with proven validity and reliability. The reliability coefficient of the scale in our study was 0.84 .

In the process of quantitative data processing, the methods of correlation analysis (Pearson correlation coefficient), comparative analysis (Mann - Whitney $U$-test) and exploratory factor analysis were applied using the Jamovi 1.0.7 statistical software. In addition, a confirmatory factor analysis and structural linear modelling were carried out in the Mplus 7 program using the robust maximum likelihood (MLR) algorithm. To assess the statistical significance of media effects in the structural model, a bootstrap analysis (5000 samples) was performed in the Mplus 7 program using the "Model indirect" function (Wang J., Wang X., 2020).

\section{Results}

The study of the structure of the questionnaire of attitudes towards inequality began with an exploratory factor analysis (EFA). The suitability of the data for the EFA is evidenced by the values of Bartlett's $\left(\chi^{2}(55)=686, p<0.001\right)$ and Kaiser - Meyer - Olkin $(\mathrm{KMO}=0.815)$ tests. Table 1 shows the results of the EFA presented by the "Minimum Residuals" method with the oblique rotation of the "Oblimin" factors. Based on the results of a parallel analysis, two correlating factors were identified (the correlation coefficient between the factors was 0.48 ), explaining $44 \%$ of the variance. The first factor included all the seven items on the Inequality Approval Scale, while the second factor was formed by the four items on the Equality Approval Scale.

For a further analysis of the structure of the questionnaire of attitudes towards inequality, a confirmatory factor analysis was carried out. The one-factor model showed unsatisfactory fit to the data: $\chi^{2}=157.07 ; d f=42 ; p<0.001 ; \mathrm{CFI}=0.766$; $\mathrm{TLI}=0.693$; RMSEA $=0.113 ; 90 \%$ confidence interval for RMSEA: 0.094-0.132; PCLOSE $=0.000 ; N=215$. The two-factor model with two correlating factors corresponding to the equality and inequality approval scales, showed significantly better, although still not entirely acceptable fit indices: $\chi^{2}=96.73 ; d f=43 ; \mathrm{p}<0.001$; $\mathrm{CFI}=0.891 ; \mathrm{TLI}=0.860 ; \mathrm{RMSEA}=0.076 ; 90 \%$ confidence interval for RMSEA: $0.056-0.097$; PCLOSE $=0.018 ; N=215$. 
Factor loadings of items in The Scale of Beliefs about Inequality $(N=215)$

\begin{tabular}{|c|c|c|}
\hline Items & Factor 1 & Factor 2 \\
\hline 1. More income equality would allow my family to live better & 0.03 & 0.71 \\
\hline $\begin{array}{l}\text { 2. More income equality would avoid conflicts between people at different } \\
\text { levels }\end{array}$ & -0.05 & 0.71 \\
\hline $\begin{array}{l}\text { 3. Incomes should be more equal, because every family's needs for food, } \\
\text { housing, and so on, are the same }\end{array}$ & 0.02 & 0.84 \\
\hline $\begin{array}{l}\text { 4. Incomes should be more equal, because everybody's contribution to } \\
\text { society is equally important }\end{array}$ & -0.13 & 0.58 \\
\hline 5. If incomes were more equal, nothing would motivate people to work hard & 0.56 & 0.04 \\
\hline $\begin{array}{l}\text { 6. Incomes cannot be made more equal since people's abilities and talents } \\
\text { are unequal }\end{array}$ & 0.55 & -0.02 \\
\hline $\begin{array}{l}\text { 7. Incomes should not be more equal since the rich invest in the economy, } \\
\text { creating jobs and benefits for everyone }\end{array}$ & 0.43 & -0.23 \\
\hline $\begin{array}{l}\text { 8. If incomes were more equal, life would be boring because people would } \\
\text { all live in the same way }\end{array}$ & 0.63 & 0.01 \\
\hline $\begin{array}{l}\text { 9. Incomes cannot be made more equal since it's human nature to always } \\
\text { want more than others have }\end{array}$ & 0.57 & 0.23 \\
\hline $\begin{array}{l}\text { 10. Incomes should not be made more equal, since that would keep people } \\
\text { from dreaming of someday becoming a real success }\end{array}$ & 0.74 & -0.03 \\
\hline $\begin{array}{l}\text { 11. Making incomes more equal means socialism, and that deprives peo- } \\
\text { ple of individual freedoms }\end{array}$ & 0.67 & -0.12 \\
\hline
\end{tabular}

Note. Factor loadings greater than 0.40 are shown in boldface.

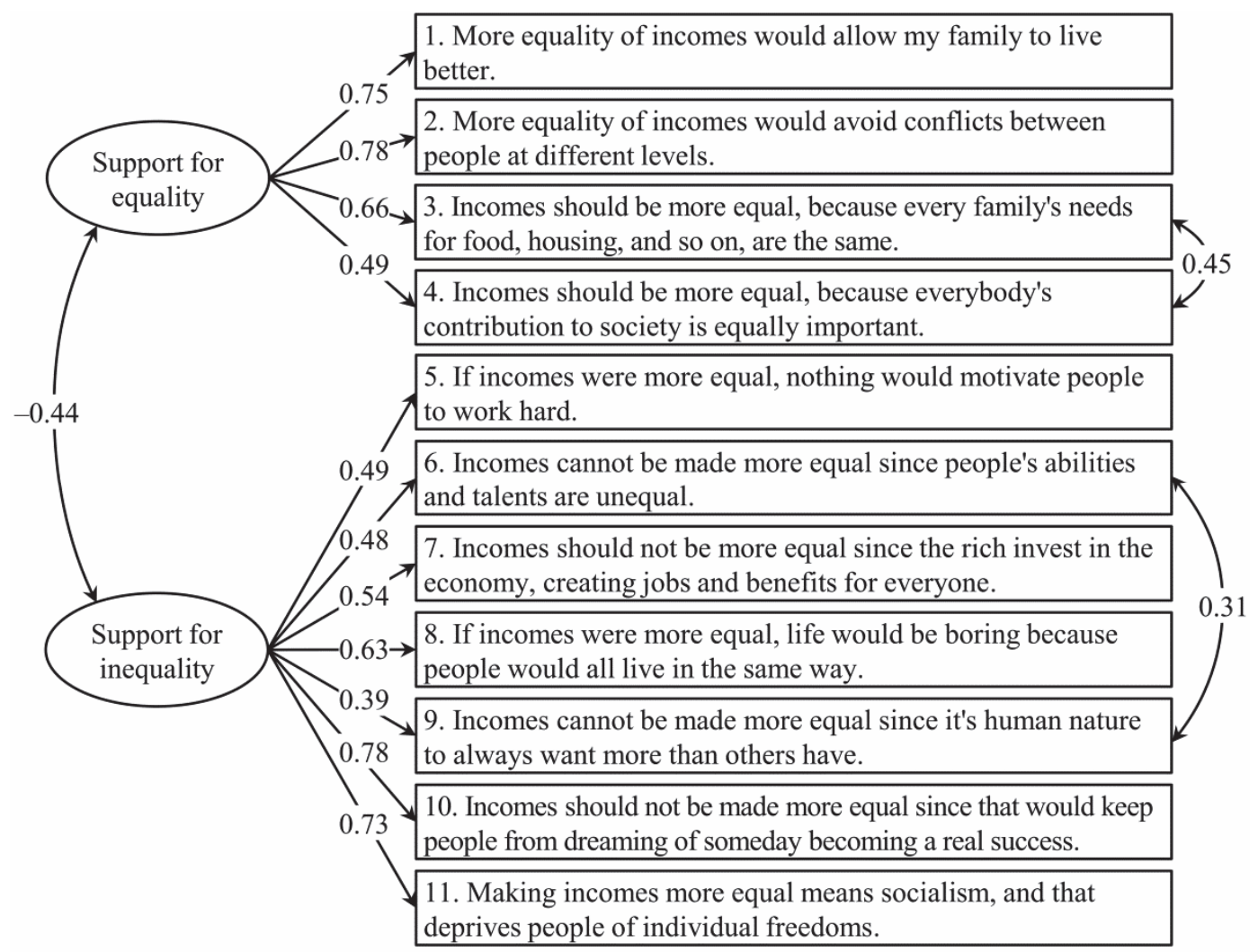

Figure 1. Russian version of The Scale of Beliefs about Inequality 
An analysis of the Lagrange Multiplier Test values showed that two covariances can be added to the model between the items with similar contents, in which similar formulations are used (see Figure 1). After these covariances were added to the model, the values of fit indices became quite acceptable: $\chi^{2}=57.61$; $d f=41 ; p<0.044$; CFI $=0.966$; TLI $=0.955$; RMSEA $=0.043 ; 90 \%$ confidence Interval for RMSEA: 0.007-0.068; PCLOSE $=0.641 ; N=215$.

Given in Table 2 Cronbach's $\alpha$ of the equality and inequality approval scales indicate their high reliability ( $\alpha$ not less than 0.78 ). The analysis of descriptive statistics suggests a weak asymmetry of the distribution by the scales (the absolute values of skewness does not exceed 0.13 ), confirming the admissibility of using parametric methods in the analysis of these scales.

Table 2

Descriptive statistics and correlations of attitude toward inequality, social beliefs and moral foundations $(N=215)$

\begin{tabular}{|c|c|c|c|c|c|}
\hline Scales and indicators & 1. AE & 2. Al & 3. BDW & 4. DJW & 5. FW \\
\hline 1. Approval of equality (AE) & - & & & & \\
\hline 2. Approval of inequality (Al) & $-0.35^{\star \star \star}$ & - & & & \\
\hline 3. Belief in a dangerous world (BDW) & $0.20^{\star *}$ & -0.12 & - & & \\
\hline 4. Belief in a jungle world (BJW) & $-0.16^{\star}$ & $0.19^{\star \star}$ & -0.03 & - & \\
\hline 5. Index of current family welfare (FW) & $-0.20^{\star \star}$ & 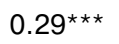 & $-0.15^{\star}$ & 0.01 & - \\
\hline 6. Coefficient of progressivism & 0.07 & -0.05 & $0.14^{\star}$ & $-0.30 * \star \star$ & -0.12 \\
\hline 7. Individualizing moral foundations & $0.19^{\star \star}$ & -0.09 & 0.09 & $-0.38^{\star \star \star}$ & -0.12 \\
\hline 8. Binding moral foundations & 0.12 & -0.04 & -0.06 & -0.09 & -0.01 \\
\hline 9. Care & $0.14^{\star}$ & -0.02 & 0.05 & $-0.36^{\star \star \star}$ & -0.09 \\
\hline 10. Fairness & $0.22^{\star \star}$ & $-0.15^{\star}$ & 0.12 & $-0.36^{\star \star \star}$ & $-0.14^{\star}$ \\
\hline 11. Loyalty & $0.13^{*}$ & -0.05 & -0.12 & -0.09 & 0.04 \\
\hline 12. Authority & 0.02 & 0.02 & -0.02 & 0.05 & 0.03 \\
\hline 13. Purity & $0.16^{\star}$ & -0.06 & 0.00 & $-0.17^{\star}$ & -0.08 \\
\hline 14. Age & -0.08 & 0.00 & -0.12 & -0.04 & $-0.38^{\star \star \star}$ \\
\hline Cronbach's $\alpha$ & 0.79 & 0.80 & 0.69 & 0.77 & 0.84 \\
\hline Mean & 3.57 & 3.05 & 3.24 & 2.45 & 2.83 \\
\hline Standard deviation & 0.76 & 0.71 & 0.46 & 0.53 & 0.69 \\
\hline Skewness & -0.13 & 0.09 & -0.06 & -0.12 & 0.13 \\
\hline Kurtosis & 0.35 & 0.63 & 1.39 & -0.07 & -0.09 \\
\hline
\end{tabular}

Note. ${ }^{*}-p<0,05 ;{ }^{* *}-p<0,01 ;{ }^{* *}-p<0,001$. The number of variables in columns corresponds to the numbers of variables in rows.

Pearson's correlation coefficients between the measured indicators (see Table 2) suggest the presence of significant association between the approval scales for equality and inequality, both with social beliefs and with moral foundations as well as with the family welfare index. In particular, the approval of equality shows a direct statistically significant correlation with the belief in a dangerous world $(0.20 ; p<0.01)$ and inverse - with the belief in a jungle world $(-0.16 ; p<0.05)$. The approval of inequality demonstrates a direct significant relationship only with the belief in a jungle world $(0.19 ; p<0.01)$. Consequently, people who believe in the danger of the world around them are more likely to prefer social equality, while those who believe in a jungle world are less likely to approve of equality and more likely to prefer inequality.

The expected correlations were obtained between the indicators of attitudes towards inequality and the index of family welfare: the inverse - for the approval 
of equality $(-0.20 ; p<0.01)$ and the direct - for the approval of inequality $(0.29$; $p<0.001)$. These correlations mean that people who assess their family's welfare relatively highly tend to prefer inequality to equality.

The correlations of the indicators of attitudes towards inequality with the coefficient of progressivism are not statistically significant, however, a significant relationship with the approval of equality was found for the individualizing moral foundations in general $(0.19 ; p<0.01)$, as well as the scales of Care $(0.14 ; p<0.05)$, Fairness $(0.22 ; p<0.01)$, Loyalty $(0.13 ; p<0.05)$ and Purity $(0.16 ; p<0.05)$. The approval of inequality showed the only weak inverse relationship with Fairness $(-0.15 ; p<0.05)$. Thus, the only moral foundation associated with both scales of attitudes towards inequality, was Fairness, and it also demonstrates the strongest connection with the approval of equality. The binding moral foundations - Loyalty and Purity - are also correlated with a positive attitude towards equality, but the association is rather weak.

The results of the correlation analysis also indicate the presence of a relationship between the moral foundations and beliefs in a jungle world: significant negative correlations were found for the moral foundations Care $(-0.36 ; p<0.001)$ and Fairness $(-0.36 ; p<0.001)$, a weak but significant relationship was also shown by Purity $(-0.17 ; p<0.05)$. The belief in a jungle world also showed a significant inverse relationship with the scale of the individualizing moral foundations $(-0.38$; $p<0.001)$ and the coefficient of progressivism $(-0.30 ; p<0.001)$. The correlations of the moral foundations with the belief in a dangerous world are not statistically significant, although the coefficient of progressivism showed a weak direct relationship with it $(0.14 ; p<0.05)$. Of interest is also the revealed weak feedback between the moral foundation Fairness and the family welfare index, which means that people with a lower level of material welfare show greater concern for fairness.

The correlations of attitudes towards inequality with Age are not statistically significant. According to the Mann - Whitney $U$-test, no statistically significant differences were found in attitudes towards inequality between men and women. Age showed a significant inverse correlation with current family welfare $(-0.38$; $p<0.001)$. The analysis of the differences between men and women using the Mann - Whitney $U$-test shows that men are more likely to believe in a jungle world $(U=3109 ; Z=2.65 ; p<0.01)$ while women are more likely to believe in a dangerous world $(U=3233 ; Z=2.39 ; p<0.05)$. In addition, the coefficient of progressivism is slightly higher in women $(U=3468.5 ; Z=2.14 ; p<0.05)$.

Taking into account the identified correlations and on the basis of theoretically substantiated hypotheses, a structural model was built in which the individualizing moral foundations, beliefs in a jungle world and family welfare were considered as the main predictors of attitudes towards equality and inequality. Moreover, demographic characteristics of the respondents (Gender and Age) were also included in the model for control. The relationships between the variables were set based on the identified significant correlations, the path coefficients that did not show statistical significance were removed from the model. Based on the analysis of the Lagrange Multiplier Test, the path from Age to the approval of equality was added to the model, where it is significant, but the corresponding pair correlation is insignificant (see Table 2). The resulting structural model (see Figure 2) showed excellent fit to the data: $\chi^{2}=17.33 ; d f=12 ; p<0.138 ;$ CFI $=0.957$; TLI $=0.935 ;$ RMSEA $=0.045$; $90 \%$ confidence Interval for RMSEA: $0.000-0.089 ;$ PCLOSE $=0.516 ; N=215$. 


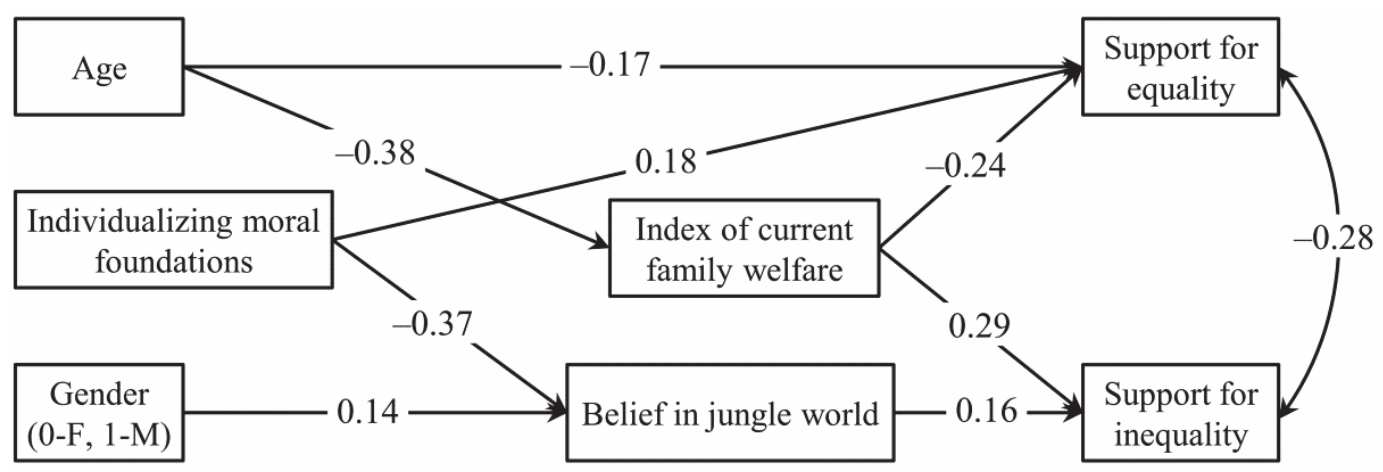

Figure 2. Structural model of relationships between the moral foundations and social beliefs in a dangerous and jungle world with attitudes towards equality and inequality (all the standardized path coefficients are significant at $p<0.05$; for the sake of parsimony, the residuals are missed).

The analysis of mediation effects showed that the effects of age on the approval of equality (standardized path coefficient $r=0.09 ; p<0.01$ ) and inequality $(r=-0.11 ; p<0.01)$ mediated through family welfare are statistically significant. The effect of the individualizing moral foundations on the approval of inequality, mediated through the belief in a jungle world, is also statistically significant $(r=-0.06 ; p<0.05)$. The effect of gender on the approval of inequality mediated by the belief in a jungle world is not significant.

\section{Discussion}

In the course of the study, we translated and tested the questionnaire for assessing attitudes towards inequality, the results of the approbation testify to its fairly good psychometric characteristics and a factor structure corresponding to our expectations. At the same time, the rather moderate inverse correlation of the factors of attitudes towards equality and inequality indicates that their content is not close enough to consider them as poles of a single construct. In this regard, it is necessary to improve the questionnaire in order to be able to measure the attitude towards equality/ inequality as a single construct. The constructive validity of the Russian version of the questionnaire is supported by the expected (based on previous studies (Roex et al., 2019)) relationship between the factors of attitudes towards inequality and the family welfare index, as well as the fact that the closest correlation with attitudes towards inequality (with both its factors) is shown by the moral foundation Fairness.

In the course of structural modelling, the dual effect of age on the approval of equality was revealed: the direct effect is inverse, while the one mediated through the current family welfare index is direct. Consequently, if the more mature respondents have a relatively low level of family material welfare, then they are more inclined to approve of equality than younger respondents are. Otherwise, they are less inclined to approve of equality.

The effect of the individualizing moral foundations on the approval of inequality, mediated through the belief in a jungle world, is rather weak, despite the fact that the relationship between the belief in a jungle world and moral foundations is quite significant. Approval of inequality depends more on family welfare than on beliefs in a jungle world and moral foundations. It is not surprising that the attitude towards inequality primarily depends on material welfare, but the results of the study indicate that the characteristics of a person's moral sphere and social beliefs also matter. 
The main conclusion that follows from the resulting structural model is that approval of inequality is supported by beliefs in a jungle world, which, in turn, is associated with a "deficiency" of individualizing moral foundations: care and fairness. A keen sense of fairness, coupled with the value of caring for the weak and defenceless, opposes the notion of a ruthless competitive society and approval of inequality. This conclusion is complemented by a psychological portrait of persons holding different positions in relation to economic inequality: staunch supporters and implacable opponents of inequality. The practical significance of the obtained results is associated with more effective party propaganda activities, taking into account the psychological characteristics of target groups.

The limitations of our study include the impossibility of generalization the results to the population of our country, since the sample consisted exclusively of students of Altai Krai. It should also be emphasized that the interpretation of the identified relationships in terms of cause-effect relationships is based only on theoretical concepts, since the design of our study does not allow us to confirm or deny the cause-effect nature of the relationships. Another limitation is associated with insufficient knowledge of the validity of the proposed Russian version of the questionnaire on attitudes towards inequality. An in-depth psychometric analysis of this technique with a thorough study of its validity constitutes the prospect for this study.

\section{Conclusion}

In the course of the study, the Russian version of The Questionnaire of Attitudes Towards Inequality by J. Kluegel and E. Smith was developed and tested, its two-factor structure and reliability in terms of internal consistency was shown as well as preliminary data were obtained in favour of the construct validity of the questionnaire.

The hypothesis of the relationship between attitudes towards inequality, moral foundations and social beliefs was confirmed. The proposed questionnaire made it possible to show, using the sample of young people in Altai Krai, that attitudes towards inequality are associated with current family welfare, beliefs in a jungle world and individualizing moral foundations, including moral norms of care and fairness.

The beliefs in a jungle world mediate the relationships between the individualizing moral foundations and approval of inequality. Beliefs in a jungle world that maintain positive attitudes towards inequality are characteristic of persons who share to a lesser extent the moral values of care and fairness.

Acknowledgements and Funding. The work was carried out with the financial support of the Russian Foundation for Basic Research, project No. 18-013-00119 "Values and moral foundations of the social worldview of youth".

\section{References}

Bullock, H.E., Williams, W.R., \& Limbert, W.M. (2003). Predicting support for welfare policies: The impact of attributions and beliefs about inequality. Journal of Poverty, 7(3), 35-56. https://doi.org/10.1300/J134v07n03_03

Duckitt, J., Wagner, C., du Plessis, I., \& Birum, I. (2002). The psychological bases of ideology and prejudice: Testing a dual process model. Journal of Personality and Social Psychology, 83(1), 75-93. https://doi.org/10.1037//0022-3514.83.1.75 
Franks, A.S., \& Scherr, K.C. (2019). Economic Issues Are Moral Issues: The Moral Underpinnings of the Desire to Reduce Wealth Inequality. Social Psychological and Personality Science, 10(4), 553-562. https://doi.org/10.1177/1948550618772821

García-Castro, J.D., Willis, G.B., \& Rodríguez-Bailón, R. (2019). I know people who can and who cannot: A measure of the perception of economic inequality in everyday life. The Social Science Journal, 56(4), 599-608. https://doi.org/10.1016/j.soscij.2018.09.008

Graham, J., Haidt, J., Koleva, S., Motyl, M., Iyer, R., Wojcik, S., \& Ditto, P.H. (2013). Moral foundations theory: The pragmatic validity of moral pluralism. Advances in Experimental Social Psychology, 47, 55-130. https://doi.org/10.1016/B978-0-12-407236-7.00002-4

Graham, J., Nosek, B.A., Haidt, J., Iyer, R., Koleva, S., \& Ditto, P.H. (2011). Mapping the Moral Domain. Journal of Personality and Social Psychology, 101, 366-385. https://doi.org/10.1037/a0021847

Gulevich, O.A., Anikeenok, O.A., \& Bezmenova, I.K. (2014). Social Beliefs: Adaptation of J. Duckitt's Scales. Psychology. Journal of Higher School of Economics, 11(2), 68-89. (In Russ.)

Haidt, J., \& Bjorklund, F. (2008). Social intuitionists' answer six questions about moral psychology. In Moral psychology. Vol 2. The cognitive science of morality: Intuition and diversity (pp. 181-217). Cambridge, MA, US: MIT Press.

Haidt, J., Graham, J., \& Joseph, C. (2009). Above and Below Left - Right: Ideological Narratives and Moral Foundations. Psychological Inquiry, 20(2-3), 110-119. https://doi.org/10.1080/10478400903028573

Khashchenko, V.A. (2011). Subjective economic well-being and its measurement: Constructing and validating a questionnaire. Experimental Psychology (Russia), 4(1), 106-127. (In Russ.)

Kim, H., Huh, S., Choi, S., \& Lee, Y. (2018). Perceptions of inequality and attitudes towards redistribution in four East Asian welfare states. International Journal of Social Welfare, 27(1), 28-39. https://doi.org/10.1111/ijsw.12266

Kluegel, J.R., \& Smith, E.R. (1986). Beliefs about Inequality: Americans' Views of What is and What Ought to be. Routledge.

Kozlova, M.A., \& Kozlov, A.I. (2016). The origins of individual-oriented and group-oriented morality: Social-psychological and scientific aspects. Psikhologicheskii zhurnal, 37(3), 60-70. (In Russ.)

Larsen, C.A. (2016). How three narratives of modernity justify economic inequality. Acta Sociologica, 59(2), 93-111. https://doi.org/10.1177/0001699315622801

Nestik, T.A., \& Zhuravlev, A.L. (2018). Psikhologiya global'nykh riskov. Moscow: IP RAN Publ. (In Russ.)

Norton, M.I., \& Ariely, D. (2011). Building a better America - One wealth quintile at a time. Perspectives on Psychological Science, 6(1), 9-12. https://doi.org/10.1177/1745691610393524

Randazzo, A., \& Haidt, J. (2015). The moral narratives of economists. Econ Journal Watch, 12(1), 49-57.

Roex, K.L., Huijts, T., \& Sieben, I. (2019). Attitudes towards income inequality: 'Winners' versus 'losers' of the perceived meritocracy. Acta Sociologica, 62(1), 47-63. https://doi.org/10.1177/0001699317748340

Sychev, O.A., Bespalov, A.M., Prudnikova, M.M., \& Vlasov, M.S. (2016). Features of Moral Foundations in Mongol, German and Russian Adolescents. Cultural-Historical Psychology, 12(1), 85-96. (In Russ.) https://doi.org/10.17759/chp.2016120109

Sychev, O.A., Protasova, I.N., \& Belousov, K.I. (2018). Diagnosing Moral Foundations: Testing of the Russian Version of the Moral Foundations Questionnaire. Russian Psychological Journal, 15(3), 88-115. (In Russ.) https://doi.org/10.21702/rpj.2018.3.5

Telin, K.O. (2019). Divergence in mind: Why inequality devil is as black as he is painted. Voprosy Ekonomiki, (4), 107-123. (In Russ.) https://doi.org/10.32609/0042-8736-2019-4-107-123

Wang, J., \& Wang, X. (2020). Structural equation modeling: Applications using Mplus. Chichester: John Wiley \& Sons.

Wiwad, D., et al. (2019). The support for economic inequality scale: Development and adjudication. PloS One, 14(6), e0218685. https://doi.org/10.1371/journal.pone.0218685 
Zaikin, V.A. (2017). Moral functioning: Socio-psychological approach. Social intuitionist theory of John Haidt. National Psychological Journal, 25(1), 32-38. (In Russ.) https://doi.org/10.11621/npj.2017.0104

Zhuravlev, A.L., \& Yurevich A.V. (2018). Izbytochnoe neravenstvo dokhodov kak ugroza bezopasnosti sovremennogo obshchestva. In A.L. Zhuravlev, \& D.A. Kitova (Eds.), Psikhologicheskie issledovaniya global'nykh protsessov: Predposylki, tendentsii, perspektivy. Moscow: IP RAN Publ. (In Russ.)

\section{Russian version of The Scale of Beliefs about Inequality by J. Kluegel and E. Smith \\ [Русскоязычная версия опросника отношения к неравенству Дж. Клуегеля и Э. Смита]}

Инструкция: оцените, пожалуйста, насколько Вы согласны с каждым из приведенных утверждений.

\begin{tabular}{|c|c|c|c|c|c|}
\hline Утверждения & $\begin{array}{l}\text { Совершенно } \\
\text { не согласен }\end{array}$ & $\begin{array}{l}\text { Скорее не } \\
\text { согласен }\end{array}$ & $\begin{array}{c}\text { Ни то, } \\
\text { ни другое }\end{array}$ & $\begin{array}{l}\text { Скорее } \\
\text { согласен }\end{array}$ & $\begin{array}{c}\text { Полностью } \\
\text { согласен }\end{array}$ \\
\hline \multicolumn{6}{|l|}{$\begin{array}{l}\text { 1. Снижение неравенства в доходах } \\
\text { позволит моей семье жить лучше }\end{array}$} \\
\hline \multicolumn{6}{|l|}{$\begin{array}{l}\text { 2. Снижение разрыва в доходах поз- } \\
\text { волит избежать многих конфликтов } \\
\text { из-за различий в уровне достатка }\end{array}$} \\
\hline \multicolumn{6}{|l|}{$\begin{array}{l}\text { 3. Нужно снижать неравенство в доходах, } \\
\text { поскольку все семьи одинаково нуж- } \\
\text { даются в пище, жилье и других вещах }\end{array}$} \\
\hline \multicolumn{6}{|l|}{$\begin{array}{l}\text { 4. Нужно снижать неравенство в доходах, } \\
\text { поскольку вклад каждого человека } \\
\text { в жизнь общества одинаково важен }\end{array}$} \\
\hline \multicolumn{6}{|l|}{$\begin{array}{l}\text { 5. При равенстве доходов у людей } \\
\text { исчезнет стимул лучше работать }\end{array}$} \\
\hline \multicolumn{6}{|l|}{$\begin{array}{l}\text { 6. Неравенства в доходах избежать } \\
\text { невозможно, так как люди изначально } \\
\text { неравны по таланту, способностям }\end{array}$} \\
\hline \multicolumn{6}{|l|}{$\begin{array}{l}\text { 7. Не нужно уравнивать доходы, так } \\
\text { как богатые приносят пользу обще- } \\
\text { ству, инвестируя в экономику и со- } \\
\text { здавая рабочие места }\end{array}$} \\
\hline \multicolumn{6}{|l|}{$\begin{array}{l}\text { 8. При равенстве в доходах все люди } \\
\text { жили бы одинаково и жизнь была бы } \\
\text { скучной }\end{array}$} \\
\hline \multicolumn{6}{|l|}{$\begin{array}{l}\text { 9. Обеспечить равенство в доходах не- } \\
\text { возможно, поскольку в человеческой } \\
\text { природе заложено хотеть большего, } \\
\text { чем имеют другие }\end{array}$} \\
\hline \multicolumn{6}{|l|}{$\begin{array}{l}\text { 10. Доходы не следует уравнивать, по- } \\
\text { скольку это помешает людям мечтать } \\
\text { о том, чтобы стать по-настоящему } \\
\text { успешными }\end{array}$} \\
\hline $\begin{array}{l}\text { 11. Уравнивание доходов приведет } \\
\text { к ограничению личной свободы }\end{array}$ & & & & & \\
\hline
\end{tabular}

Шкала «Одобрение равенства»: 1, 2, 3, 4 .

Шкала «Одобрение неравенства»: 5, 6, 7, 8, 9, 10, 11.

Для получения итоговых показателей по шкалам вычисляются средние значения оценок (от 1 - «Совершенно не согласен» до 5 - «Полностью согласен») по заданиям, входящим в каждую шкалу. 
Article history:

Received: 27 April 2020

Revised: 23 September 2020

Accepted: 15 October 2020

\title{
For citation:
}

Sychev, O.A., \& Protasova, I.N. (2020). The Relationships between Moral Foundations, Social Beliefs and Attitudes towards Economic Inequality among Russian Youth: A Case Study of Altai Krai. RUDN Journal of Psychology and Pedagogics, 17(4), 705-718. http://dx.doi.org/10.22363/2313-1683-2020-17-4-705-718

\section{Bio notes:}

Oleg A. Sychev, Ph.D. in Psychology, is research fellow of Shukshin Altai State University for Humanities and Pedagogy (Biysk, Russia). ORCID iD: https://orcid.org/0000-00020373-6916; eLIBRARY SPIN-code: 2849-5161.E-mail: osn1@mail.ru

Irina N. Protasova, Ph.D. in Psychology, Associate Professor, is Associate Professor of Chair of Pedagogy and Psychology of Shukshin Altai State University for Humanities and Pedagogy (Biysk, Russia). ORCID iD: https://orcid.org/0000-0002-7728-705X; eLIBRARY SPIN-code: 1550-7557. E-mail: protasovain@mail.ru

Исследовательская статья

\section{Связь морали и социальных верований с отношением к экономическому неравенству у российской молодежи: на примере Алтайского края}

\author{
О.А. Сычев, И.Н. Протасова
}

Алтайский государственный гуманитарно-педагогический университет имени В.М. Шукшина, Российская Федераџия, 659333, Бийск, ул. Владимира Короленко, 53

Аннотация. В статье приведены результаты эмпирического исследования связи между моральными основаниями, социальными верованиями и отношением к экономическому неравенству. Проблема отношения к экономическому неравенству традиционно рассматривалась преимущественно социологами и экономистами в контексте групповых различий, в то время как его психологические факторы и корреляты остаются недостаточно изученными. Негативные последствия экономического неравенства могут быть опосредованы психологическими механизмами: субъективным восприятием существующего неравенства, отношением к нему, что свидетельствует об актуальности этой проблемы. В исследовании была выдвинута гипотеза о том, что отношение к экономическому неравенству у молодежи связано с моральными основаниями и социальными верованиями. Для ее проверки было проведено исследование на выборке из 215 студентов (21\% мужчин). Испытуемые отвечали на вопросы шкал веры в опасный и конкурентный мир Дж. Даккита, опросника моральных оснований Дж. Грэхема и соавторов, опросника убеждений относительно источников и последствий неравенства в доходах Дж. Клуегеля и Э. Смита. Разработка русскоязычной версии опросника Дж. Клуегеля и Э. Смита, представленной в приложении к статье, стала одной из задач данного исследования. Корреляции показывают, что отношение к неравенству связано с моральными 
основаниями (справедливости, чистоты и лояльности) и верой в конкурентный мир. $\mathrm{C}$ помощью путевого анализа продемонстрировано, что одобрение равенства и неравенства наиболее тесно связано с благосостоянием семьи. Связь отношения к неравенству с индивидуализирующими моральными основаниями опосредована верой в конкурентный мир. Таким образом, чувство справедливости и ценности заботы о слабых и беззащитных противостоят вере в конкурентный мир и одобрению неравенства.

Ключевые слова: экономическое неравенство, теория моральных оснований, справедливость, социальные верования, вера в конкурентный мир

Благодарности и финансирование. Работа выполнена при финансовой поддержке РФФИ, проект № 18-013-00119 «Ценностные и моральные основы социального мировоззрения молодежи».

\section{История статьи:}

Поступила в редакцию: 27 апреля 2020 г.

Принята к печати: 15 октября 2020 г.

\section{Для цитирования:}

Sychev O.A., Protasova I.N. The Relationships between Moral Foundations, Social Beliefs and Attitudes towards Economic Inequality among Russian Youth: A Case Study of Altai Krai // Вестник Российского университета дружбы народов. Серия: Психология и педагогика. 2020. Т. 17. № 4. С. 705-718. http://dx.doi.org/10.22363/2313-16832020-17-4-705-718

\section{Сведения об авторах:}

Сычев Олег Анатольевич, кандидат психологических наук, доцент, научный сотрудник Алтайского государственного гуманитарно-педагогического университета имени B.M. Шукшина (Бийск, Россия). ORCID iD: https://orcid.org/0000-0002-0373-6916; eLIBRARY SPIN-код: 2849-5161. E-mail: osn1@mail.ru

Протасова Ирина Николаевна, кандидат психологических наук, доцент, доцент кафедры психологии и педагогики Алтайского государственного гуманитарнопедагогического университета имени B.M. Шукшина (Бийск, Россия). ORCID iD: https://orcid.org/0000-0002-7728-705X; eLIBRARY SPIN-код: 1550-7557. E-mail: protasovain@mail.ru 